\title{
THE RELATION BETWEEN INDUSTRY AND PROVINCES IN FOREST MANAGEMENT
}

\author{
BY J. A. BRODIE ${ }^{1}$
}

\section{INTRODUCTION}

Traditionally forest industries have been the first to enter into the great undeveloped regions of Canada. They have carried the heavy capital costs of building new roads, new communities and conversion plants. Foresters and forest industry take pride in their accomplishments in pioneering and opening up new territories but should this process continue longer and extend too far afield we may eventually expire in the treeless tundras of the north. Our location geographically needs to be stabilized.

The population increase has accelerated land use pressures at a rate undreamed of only a few years ago. More sportsmen need more forest land on which to hunt and fish. More recreationists need lands for cottages, to picnic, hike and camp. More lands are flooded to supply water for power developments, domestic and industrial uses and a closer scrutiny reveals that other industrial and non-industrial uses of land enter into play making deep inroads into the once undisputed realm of forest industry and the forester.

\section{Importance Of Forest Product Industries In Canada}

The forest products industries of Canada employ nearly 300,000 persons and pay out one billion, two hundred million dollars in wages each year. Our forest based industries are first in terms of employment, wages paid, freight loading and net value of the output production in dollars. The lumber industry comprises over 8000 small and medium sized and a few large mills. The pulp and paper industry has grown over a period of 50 years to become Canada's leading manufacturing industry with some 130 large pulp and paper plants. These plants form the industrial framework of most of our northern communities.

Demand prospects for forest products which have been thoroughly analyzed over the past few years indicate a possible doubling of production over a twenty year period.

\section{Federal-Provincial Agreements}

Under the provisions of the Department of Forestry Act the government of Canada assists the provinces financially in many fields associated with the management of the provincial forest resource. This has included a sharing of the cost of inventory, reforestation programs, capital costs of fire protection services, construction costs of access roads and stand improvement operations. The federal share of the cost is $50 \%$ and latterly all ten

\footnotetext{
${ }^{1}$ Chief, Timber Branch, Department of Lands and Forests, Toronto, Ont.
} 
provinces have participated. Since the forestry agreements were first implemented in 1951 the federal government has contributed a total of 32 million dollars under these cost sharing agreements.

Federal-provincial co-operation in renewable resource management was given its greatest impetus by the Resources for Tomorrow conference held in Montreal in October 1961. Following the conference, a Resource Ministers' Conference was established in 1962 composed of a federal Cabinet Minister and one from each of the provincial governments. Co-operation in forest management between the two senior levels of government has grown to this satisfactory level in the short period of a little over a decade.

The Relations Between Industry And Provinces In Forest Management

First let us stress two characteristics of the forest situation which are uniquely Canadian. At Confederation the natural resources including forests were handed over to the administration of the provinces and secondly, it has been the policy of all provinces to retain forests and forest lands in provincial ownership. As a result, the relation with which we are dealing, when viewed for Canada as a whole, is one between the province as owner and industry as the operator of our forest resource.

Timber for the use of industry is sold by some system of public sale, or otherwise disposed of through a licensing system. Licences to cut timber grant only the right (usually an exclusive right) to cut and use the timber. The property right to the timber remains in the Crown until the timber is felled, when it becomes the property of the licensee usually subject to the final payment of royalty and other Crown charges. Under the licensing system in Ontario and, I believe, also in other provinces, there is no way in which a licensee may own standing timber on Crown lands. For example, if a licensee plants trees on a Crown licensed area, these trees become the exclusive property of the Crown.

In sharp contrast to the principle of public ownership of the forest resource, logging, from the felling of the tree and use thereafter, is strictly private enterprise. Forest industry, highly experienced in logging and manufacturing cannot be expected to show a financial interest in standing timber which it does not, nor cannot, own under the usual licensing system in vogue in Canada.

It is of importance to recognize clearly these conditions because traditionally in timber management operations and silviculture, logging has been the instrument through which silvicultural objectives have been attained. Logging operations will probably continue to shift from hand methods to increasing mechanization if Canadian industry is to remain competitive and capture a proportion of increasing world markets. Should we not be looking towards a greater separation between logging and silviculture? Logging would be left to develop along purely economic lines and silviculture would discard strip cutting, shelterwood and other methods carried out through the logging process. Silviculture stands to benefit as much as logging from this separation.

RESOURCES INVENTORY

A complete new inventory of the forest resources of Ontario using the aerial photographic method was started in 1946 and completed in 1957. The 
inventory is now being revised on a schedule to be completed in 1967. Inventory includes aerial photography, a planimetric mapping program, preparation of forest type maps, making of timber estimates and drawing up management plans. All of these operations are carried out by the province for unlicensed Crown lands. All lands are photographed and planimetric maps prepared at the expense of the province.

The preparation of inventory and management plans by licensees is a statutory requirement in Ontario. In practice, licensees having a total area in excess of 50 square miles, prepare forest type maps, timber estimates and management plans for the area under licence at their expense; under rather general minimum specifications set by the Crown. On the request of the licensee the province supplies prints of aerial photographs at $\$ 1.00$ per print and copies of planimetric maps at the cost of printing. The system has worked well and very excellent inventories and management plans have been prepared by industry to compiete the provincial inventory program. It seems desirable to continue this procedure as management planning serves logging as well as overall resource management.

\section{REGENERATION}

Generally in Ontario about one-third of the forest lands cut over annually require some aid in regeneration if the ensuing stand is to be capable of producing in species and quantities of timber the equivalent of the stand before cutting. Aid in regeneration takes the form of scarification with or without seeding, various methods of seeding, spraying to control brush, but the greatest reliance is placed on planting. The present targets for nursery production of tree seedlings in Ontario is 60 million annually. Fifteen million trees are distributed annually to private land owners, 5 million are planted on County and Authority forests, and some 40 million are planted on Crown lands both licensed and unoccupied.

It is the plan of the provinces, not yet fully in operation, that the costs of regeneration aids will be shared by the two senior levels of government. Co-operation with industry is in the initial stages of development. Established industry with their more or less fixed areas of economic supply of wood show a radiness to co-operate with the province, in making their facilities and manpower available to the province under agreement. The cost-benefit results of keeping forest lands close to the mill highly productive are impressive.

\section{STAND IMPROVEMENT}

The regeneration program merges almost imperceptibly into the care of the growth and health of the forest from seedling to maturity. Stand improvement includes the many operations of thinnings, removal of wolf or poorly formed trees and undesirable species and the marking of trees for removal in commercial logging operations. Many of the small licences and permit operations are of a stand improvement nature. In cases where the product will not pay the cost of operations, stand improvements are carried out by junior rangers during the summer months and frequently as aids to employment during some of the winter months. 


\section{CONCLUDING REMARKS}

In spite of the large unused allowable cut in Canada, growth of our forest industries has been much slower in recent years than world averages. Assuming those factors of climate, geography and growing stock especially fixed by nature, the variable factors, which are assuming an ever-increasing importance in limiting the realization of the potential of our forests, are the demands for returns from the forest by labour, government and investors in the form of wages, taxes and profits. Because of these higher demands expansion of Canadian forest industry can proceed only as timber of superior quality is available at low cost.

We need high quality timber for which there is a market! Let me give one example: Eastern white pine is one of our species for which the cut is restricted by the availability of physical resources. In Ontario, 50 years ago we were cutting about one billion board feet; today the annual cut approximates 130 million feet. These stands were cut at a time when little was done to ensure well stocked stands of valuable species after logging. Most of this very accessible area is producing timber of species and quality which must compete with an almost unlimited supply of similar but cheaper wood closer to consuming centers. There is a ready market for high quality pine.

We need availability at low cost! Forest industry cannot move farther and farther into the hinterland as accessible areas are cut over and still even maintain its present competitive position in world markets. Added to this are pressures for other uses of accessible forest lands. To improve our competitive position by reducing costs requires an increasing tempo of forest management on the more highly productive accessible lands. Industry has been aggressive in introducing technological advances in logging which are reducing costs. To aid this process it is suggested that, at least for the time being, there should be a separation between logging and silviculture in order that each may develop separately towards purely economic, low cost objectives.

Governments are deeply concerned with maintaining a steady growth in the Canadian economy. Our most favourable area of growth potential is in the forest based industry with an adequate resource base, featured by an allowable cut at least three times the actual annual cut. No other sector of our economy offers as favourable prospects for growth. In view of this direct public interest it is finally suggested that the two senior levels of government share the costs of silviculture. 